\title{
Analisis Model Pembelajaran Demonstrasi Untuk Meningkatkan Kualitas Pembelajaran Di Kelas
}

\author{
Nisa Siti Rahmadona ${ }^{1}$, Nana $^{2}$ \\ Pendidikan Fisika \\ Fakultas Keguruan dan Ilmu Pendidikan, Universitas Siliwangi \\ @182153002@gmail.com
}

\begin{abstract}
Abstrak
Metode demonstrasi adalah metode penyajian pelajaran dengan memperagakan dan mempertunjukkan kepada siswa tentang suatu proses, situasi atau benda tertentu, baik sebenarnya atau hanya sekadar tiruan. Sebagai metode penyajian, demonstrasi tidak terlepas dari penjelasan secara lisan oleh guru. Walaupun dalam proses demonstrasi peran siswa hanya sekadar memperhatikan, akan tetapi demonstrasi dapat menyajikan bahan pelajaran lebih konkret. Dalam strategi pembelajaran, demonstrasi dapat digunakan untuk mendukung keberhasilan strategi ekspositori dan inkuiri. Tujuan dari penelitian ini adalah untuk meningkatkan aktivitas dan hasil belajar siswa dalam pembelajaran sains di kelas.
\end{abstract}

Kata Kunci : Pembelajaran Demonstrasi, Kualitas Pembelajaran

Pendahuluan

Berdasarkan hasil belajar dan pengamatan awal tersebut nampak jelas terjadi kesenjangan antara harapan pembelajaran IPA dengan kenyataan yang terjadi di lapangan atau di kelas. Persoalan sekarang adalah bagaimana mencari cara/metode pembelajaran yang baik untuk menyampaikan berbagai konsep IPA yang diajarkan sehingga siswa dapat menggunakan dan mengingat lebih lama konsep tersebut. Salah satu alternatif untuk mengatasi masalah tersebut adalah penerapan metode demonstrasi dalam pembelajaran IPA.
Metode demonstrasi merupakan metode yang sederhana untuk mempertunjukkan proses terjadinya suatu peristiwa atau benda sampai pada penampilan tingkah laku yang dicontohkan. Metode demonstrasi dapat mengantar siswa untuk memahami materi ajar yang masih bersifat abstrak dan bersifat teoritis. Metode demonstrasi cocok bagi pembelajaran siswa sekolah dasar dalam usia 7 sampai dengan 11 tahun. Pada usia ini siswa belum mampu berpikir secara abstrak, melainkan pembelajaran perlu melibat pengalaman langsung, bentuk konkret dalam upaya mengerti tentang alam sekelilingnya. 
Penegasan ini sejalan dengan hasil pemikiran Subini (2012:157) yang menegaskana "kemampuan anak pada tahap ini (7-11 tahun) masih dalam bentuk konkret, mereka belum mampu berpikir abstrak, sehingga mereja juga hanya menyelesaikan soal-soal pembelajaran yang bersifat konkret. Aktivitas pembelajaran yang melibatkan siswa dalam pengalaman langsung sangat efektif dibandingkan penjelasan guru dalam bentuk verbal (kata-kata)."

Demonstrasi merupakan salah satu bentuk metode pembelajaran dalam proses belajar mengajar. Melalui demonstrasi, seorang guru mempertunjukkan materi ajar kepada siswa baik menyangkut fakta, kejadian, maupun konsep-konsep pengetahuan. Secara leksikal, kata „demonstrasiee berarti peragaan yang dipertunjukkan dengan melakukan suatu cara-cara menerapkan sesuatu, selanjutkan kata „berdemonstrasie berarti mengadakan pergaan. Sedangkan kata „metode ${ }^{e c}$ berarti cara sistematis dan berpikir secara baik untuk mencapai tujuan. Metode juga berarti prinsip dan praktek-praktek pengajaran (dalam Fajri dan Aprilia Senja, 2008:565). Selanjutnya menurut Susanto (2013:153) metode secara harafiah diartikan dengan „,cara"e. Dalam pemakaian yang umum diartikan sebagai cara melakukan suatu kegiatan atau cara melakukan suatu kegiatan atau cara melakukan pekerjaan dengan menggunakan fakta dan konsep-konsep secara sistematis.

Metode demonstrasi adalah metode mengajar dengan cara memperagakan barang, kejadian, aturan, dan urutan melakukan suatu kegiatan, baik secara langsung maupun melalui penggunaan media pengajaran yang relevan dengan pokok bahasan atau materi yang sedang disajikan (Muhibbin Syah, 2008:22). Metode demonstrasi adalah pertunjukan tentang proses terjadinya suatu peristiwa atau benda sampai pada penampilan tingkah laku yang dicontohkan agar dapat diketahui dan dipahami oleh peserta didik secara nyata atau tiruannya (Syaiful Bahri dan Aswan Zain, 2008:210). Jadi demonstrasi merupakan praktek yang diperagakan oleh guru atau pemandu kepada siswa. Pembelajaran dengan metode demonstrasi sangat sesuai jika terdapat keterbatasan alat-alat peraga. Penelitian yang dilakukan oleh Y.M. Adekoya (2011) menghasilkan kesimpulan bahwa metode demonstrasi memberikan peningkatan prestasi belajar siswa.

Berdasarkan beberapa pengertian tersebut, maka dapat disimpulkan bahwa metode demonstrasi merupakan cara atau metode yang digunakan untuk mempertunjukan atau memperagakan materi 
pelajaran. Dengan mempertunjukan benda atau peristiwa yang sudah dipelajari, maka materi pelajaran akan lebih mudah dipahami oleh siswa. Dengan kata lain, metode demonstrasi bertujuan untuk menjelaskan konsep atau materi yang abstrak. Artinya, metode demonstrasi merupakan yang lebih afektif dalam membantu siswa untuk mencari jawaban/solusi dengan usaha sendiri berasarkan fakta atau data yang benar.

Menurut temuan Susilawati at al. ( 2013 ) metode demonstrasi merupakan metode yang memperagakan suatu proses untuk memperoleh pengetahuan. Dengan memperlihatkan atau memperagakan suatu proses atau peristiwa secara sistematis dapat memberikan pengalaman belajar yang menyenangkan untuk siswa. Pembelajaran IPA dengan menggunakan metode demonstrasi diharapkan dapat membantu meningkatkan keaktifan peserta didik yang berujung peningkatan hasil belajar siswa. Keaktifan peserta didik ini menurut Baharudin ( 2010 ) penting agar pengalaman belajar tersebut dapat digunakan untuk menemukan prinsipprinsip bagi diri mereka sehingga peserta didik memiliki ketrampilan berpikir yang kritis. Dengan adanya beberapa permasalahan tersebut maka peneliti akan berusaha untuk melaksanakan pembelajaran yang dapat memotivasi peserta didik agar aktivitas dan hasil belajar peseta didik meningkat dan dapat mencapai target yang telah ditetapkan. Metode demonstrasi sangat membantu untuk meningkatkan pemahaman konsep pada peserta didik karena dengan metode demonstrasi konsep IPA tidak lagi bersifat abstrak. Peserta didik lebih mudah memahami materi yang ditunjukkan secara nyata melalui kegiatan demonstrasi. Informasi yang diperoleh juga akan tersimpan lebih lama dalam memori, demikian temuan Hakim,K at al. ( 2013). Sedangkan dari penelitian Zarkasi,H at al. ((2013) disebutkan pembelajaran dengan metode demonstrasi dapat meningkatkan hasil belajar maupun keterampilan proses sains siswa.

Ada banyak metode yang terfokus kepada siswa yaitu metode demonstrasi, metode proyek, metode diskusi dan metode tugas serta resistasi. Metode demonstrasi adalah suatu metode yang cara penyajian pelajaran dengan memperagakan atau mempertunjukkan kepada peserta didik suatu proses, situasi atau benda tertentu yang sedang dipelajari baik dalam bentuk tiruan yang dipertunjukkan oleh guru atau sumber belajar lain yang ahli dalam topik bahasan (Sumantri, 2001:82). Pendapat lain menyatakan bahwa metode demonstrasi adalah metode yang digunakan untuk 
memperlihatkan suatu proses atau cara kerja suatu benda yang berkenaan dengan pembelajaran. Berdasarkan teori yang dijelaskan oleh para ahli, metode demonstrasi cocok digunakan pada pembelajaran fisika khususnya pada materi listrik dinamis karena materi listrik dinamis merupakan materi yang banyak menunjukkan suatu proses atau cara misalnya proses aliran elektron pada rangkaian listrik dan cara mengukur besaranbesaran listrik.

Metode Penelitian

Pada penelitian kali ini, menggunakan metode penelitian studi pustaka. Metode penelitian studi pustaka adalah jenis penelitian yang digunakan untuk mengumpulkan informasi dan data secara mendalam melalui berbagai dokumen, buku catatan, majalah, referensi lain, dan hasil penelitian sebelumnya yang terkait, guna mendapatkan jawaban landasan teori atas pertanyaan yang akan diteliti (Yaniawati, 2020).

\section{Hasil dan Pembahasan}

\section{A. Pengertian Demonstrasi}

Demonstrasi adalah metode mengajar dengan cara memperagakan barang, kejadian, aturan, dan urutan melakukan suatu kegiatan, baik secara langsung maupun melalui penggunaan media pengajaran yang relevan dengan pokok bahasan atau materi yanga sedang disajikan. Metode demonstrasi adalah metode yang membuat perhatian siswa dapat berpusat pada apa yang didemonstrasikan. Jadi, proses siswa akan lebih terarah dan akan mengurangi perhatian siswa pada masalah lain, dapat merangsang siswa untuk lebih aktif dalam mengikuti proses belajar, dapat menambah pengalaman siswa, dapat membantu siswa mengingat lebih lama tentang materi yang disampaikan, dapat mengurangi kesalah fahaman karena pengajaran lebih jelas dan kongkrit, dapat menjawab semua masalah yang timbul di dalam pikiran setiap siswa karena ikut serta berperan secara langsung, memupuk perkembangan dan keberanian, mengambil inisiatif, bertanggung jawab dan berdiri sendiri, sehingga hasil belajar sesuai dengan apa yang diharapkan.

Demonstrasi menurut Sumantri Mulyani dan Johar Permana (2001 : 133), Metode demonstrasi diartikan sebagai cara penyajian pelajaran dengan memperagakan dan 
mempertunjukkan kepada peserta didik suatu proses, situasi atau benda tertentu yang sedang dipelajari baik dalam bentuk sebenarnya maupun dalam bentuk tiruan yang dipertunjukkan oleh guru atau sumber belajar lain yang memahami atau ahli dalam topik bahasan yang harus didemonstrasikan.

metode demonstrasi menurut Syah (2000:208) adalah metode mengajar dengan cara memperagakan barang, kejadian, aturan dan urutan melakukan kegiatan, baik secara langsung maupun melalui penggunaan media pengajaran yang relevan dengan pokok bahasan atau materi yang sedang disajikan.Metode demonstrasi di dalam pembelajaran Fisika adalah metode dimana guru menyajikan suatu percobaan Fisika di depan kelas atau di tempat yang dapat dilihat oleh seluruh siswa. Setelah mengikuti demonstrasi baik demonstrasi proses maupun demonstrasi hasil, siswa akan memperoleh

pengalaman belajar langsung setelah melihat atau melakukan pengamatan sendiri apa yang didemonstrasikan.
B. Karakteristik Demonstrasi

Ada beberapa karakteristik metode

demonstrasi menurut Winataputra (2005:418) adalah sebagai berikut:

(1) Mempertunjukan objek sebenarnya.

(2) Ada proses peniruan.

(3) Ada alat bantu.

(4) memerlukan tempat yang strategis yang memungkinkan seluruh siswa aktif.

(5) Dapat guru atau siswa yang melakukannya.

C. Kelebihan dan Kekurangan Demonstrasi

Metode demonstrasi memiliki keunggulan sebagai berikut: tidak banyak memerlukan peralatan laboratorium; penggunaan bahan praktikum tidak boros; pengembangan konsep terarah;konsep yang dipelajari akan lebih mudah diingat karena siswa melihat fakta-fakta secara langsung.; Membuat pengajaran menjadi lebih jelas dan lebih konkret;Siswa lebih mudah memahami apa yang dipelajari; Proses pengajaran lebih menarik 
; Siswa dirangsang untuk aktif mengamati, menyesuaikan antara teori dengan kenyataan. Kelemahan-

kelemahan Metode Demonstrasi Metode demonstrasi memiliki kelemahan sebagai berikut: Jika siswa sama sekali tidak diberikan pertanyaan-pertanyaan tentang halhal yang akan terjadi pada kegiatan demonstrasi, maka materi yang didemontrasikan hanya merupakan tontonan; Jika sajian demonstrasi tidak dapat dilihat oleh semua siswa, maka materi ajar tetap saja tidak terserap dengan baik; Siswa tidak terlatih dalam keterampilan penggunaan alat.; Memerlukan keterampilan guru secara khusus ; Fasilitas seperti peralatan, tempat dan biaya yang memadai tidak selalu tersedia dengan baik; Memerlukan kesiapan dan perencanaan yang matang disamping memerlukan waktu yang cukup panjang

D. Langkah - langkah Demonstrasi

1) Tahap persiapan

Pada tahap persiapan ini ada beberapa hal yang harus dilakukan antara lain:

- Rumuskan tujuan yang harus dicapai oleh peserta didik setelah proses demonstrasi berakhir. Tujuan ini meliputi beberapa aspek seperti aspek pengetahuan dan keterampilan tertentu.

- Persiapkan garis-garis besar langkah-langkah demonstrasi yang akan dilakukan. Hal ini dilakukan untuk menghindari kegagalan.

- Lakukan uji coba demonstrasi. Uji coba meliputi segala peralatan yang diperlukan.

2) Tahap pelaksanaan

- Langkah pembukaan Sebelum demonstrasi dilakukan ada beberapa hal yang harus dilakukan antara lain:

1. Aturlah tempat duduk yang memungkinkan semua peserta didik dapat melihat dengan jelas apa yang didemonstrasikan.

2. Kemukakan tujuan apa yang harus dicapai peserta didik.

3. Kemukakan tugas-tugas apa yang harus dilakukan oleh peserta didik, misalnya ditugaskan untuk mencatat halhal yang penting dari pelaksanaan demonstrasi. 
- Langkah pelaksanaan demonstrasi

1. Mulailah demonstrasi dengan kegiatan-kegiatan yang merangsang peserta didik untuk berfikir. Misalnya pertanyaanpertanyaan yang mengandung teka-teki sehingga mendorong peserta didik tertarik untuk memperhatikan demonstrasi.
2. Ciptakan suasana yang menyejukkan dan menghindari suasana yang menegangkan.

3. Yakinkan bahwa semua peserta didik mengikuti jalannya demonstrasi.

4. Berikan kesempatan kepada peserta didik untuk secara aktif memikirkan lebih lanjut sesuai dengan apa yang dilihat dari proses demonstrasi.

\section{E. Kesimpulan}

Jadi, proses siswa akan lebih terarah dan akan mengurangi perhatian siswa pada masalah lain, dapat merangsang siswa untuk lebih aktif dalam mengikuti proses belajar, dapat menambah pengalaman siswa, dapat membantu siswa mengingat lebih lama tentang materi yang disampaikan, dapat mengurangi kesalah fahaman karena pengajaran lebih jelas dan kongkrit, dapat menjawab semua masalah yang timbul di dalam pikiran setiap siswa karena ikut serta berperan secara langsung, memupuk perkembangan dan keberanian, mengambil inisiatif, bertanggung jawab dan berdiri sendiri, sehingga hasil belajar sesuai dengan apa yang diharapkan.

\section{Daftar Pustaka}

Hakim,K, Akhdinirwanto RW dan Ashari ,2013, Penerapan Metode Demonstrasi oleh Tutor Teman Sebaya untuk Peningkatan Pemahaman Konsep IPA Siswa Kelas VII SMP Negeri 9 Purworejo Tahun Pelajaran 2012/2013, Jurnal Radiasi,vol 3 no $2: 174$ - 176.

Muhibbin Syah. (2008). Psikologi Belajar. Jakarta : Raja Grafindo Persada.

Nurhayati, Fadilah S, Mutmainnah, 2014. Penerapan Metode Demonstrasi Berbantu Media Animasi Software Phet Terhadap Hasil Belajar Siswa Dalam Materi Listrik Dinamis Kelas X Madrasah Aliyah Negeri 1 Pontianak, Jurnal Pendidikan Fisika dan Aplikasinya (JPFA), vol 4 No 2.

Susilawati, Fihrin dan I Wayan Darmadi, 2013, Perbandingan Hasil Belajar Fisika antara Metode Pictorial Riddle dan Metode Demonstrasi dalam Pembelajaran Inquiry Terbimbing pada 
siswa kelas VIII SMP Negei 19 Palu, Jurnal Pendidikan Fisika Tadulako (JPFT) vol 1 no $3: 8-12$.

Sumantri, M. 2001. Pengertian Metode Demonstrasi. [Online]. Tersedia: http://www. Elfitriastikawati. Blogspot.com /2012/09. Html [2 Februari 2014].

Zarkasi,H, Maharta,N dan Suyatna,A, 2013, Perbandingan Hasil Belajar Metode Bermain Peran Menggunakan Multiple Representation ( MR ) Gesture dengan Metode Demonstrasi, Jurnal Pembelajaran Fisika, vol 1 no $6: 79-89$.

Suliman, Sarwanto, Suparmi, 2017. Pendekatan Saintifik Pada Pembelajaran Fisika Dengan Metode Eksperimen dan Demonstrasi Ditinjau dari Kemampuan Berpikir Abstrak dan Kemampuan Analisis Siswa. Jurnal Inkuiri, vol. 6 no 1:21-30. 